Tropical Journal of Pharmaceutical Research September 2019; 18 (9): 1873-1879

ISSN: 1596-5996 (print); 1596-9827 (electronic)

(1) Pharmacotherapy Group, Faculty of Pharmacy, University of Benin, Benin City, 300001 Nigeria.

\title{
Gastroprotective and ulcer healing properties of ethanol extract of Alpinia conchigera rhizome in experimentally- induced gastric ulcer in rats
}

\author{
Xin Jin ${ }^{1}$, Qiang Liu ${ }^{2}$, Minyan Dang ${ }^{3}$, Wenzhi Zhang ${ }^{3}$, Xia $\mathrm{Li}^{4 *}$ \\ ${ }^{1}$ General Surgery Department, Ankang Central Hospital, Shaanxi 725000, ${ }^{2}$ Department of Gastroenterology, Liaocheng Women \\ and Children Health, Shandong Province 252000, China, ${ }^{3}$ Innoscience Research Sdn Bhd, Suites B-5-7, Skypark@One City, \\ Jalan USJ 25/1, 47650 Subang Jaya, Selangor Malaysia, ${ }^{4}$ Department of Chinese Medicine, Jinan Central Hospital, No. 105, \\ Jie Fang Road, Li Xia District, Jinan, Shandong Province 250013, China
}

${ }^{*}$ For correspondence: Email: xli670@yahoo.com

Sent for review: 17 August 2018

Revised accepted: 21 August 2019

\begin{abstract}
Purpose: To investigate the gastroprotective effect of Alpinia conchigera rhizome in an ulcer rat model. Method: Sprague-Dawley rats were treated with ethanol extract of Alpinia conchigera at doses of 75 and $150 \mathrm{mg} / \mathrm{kg}$ body weight. After 28 days, the rats were sacrificed. Ulcer index, total acidity, $\mathrm{pH}$, hemoglobin levels, and hemorrhagic lesions were determined through macroscopic assessment and histopathological examination. The levels of lipid peroxidation (LPO), superoxide dismutase (SOD), and catalase (CAT), and inflammatory markers (TNF- $\alpha, I L-1 \beta$, and IL-6) were also determined.

Results: Alpinia conchigera significantly reduced ulcer index, total acidity, $\mathrm{pH}$ and hemoglobin levels ( $p$ $<0.05)$. Results from histology revealed that the extract protected the mucosa from lesions. Moreover, the extract significantly enhanced gastric mucosal activities of SOD and CAT, and decreased LPO levels and plasma concentrations of TNF- $\alpha, I L-1 \beta$, and IL- $6(p<0.05)$.

Conclusion: These results validate the traditional claims on the gastroprotective effects of Alpinia conchigera as revealed through its antioxidant and ulcer-healing properties by stimulation of important cellular mechanisms.
\end{abstract}

Keywords: Alpinia conchigera, Antioxidant enzymes, Gastric ulcer, Inflammatory cytokines

\begin{abstract}
This is an Open Access article that uses a fund-ing model which does not charge readers or their institutions for access and distributed under the terms of the Creative Commons Attribution License (http://creativecommons.org/licenses/by/4.0) and the Budapest Open Access Initiative (http://www.budapestopenaccessinitiative.org/read), which permit unrestricted use, distribution, and reproduction in any medium, provided the original work is properly credited.

Tropical Journal of Pharmaceutical Research is indexed by Science Citation Index (SciSearch), Scopus, International Pharmaceutical Abstract, Chemical Abstracts, Embase, Index Copernicus, EBSCO, African Index Medicus, JournalSeek, Journal Citation Reports/Science Edition, Directory of Open Access Journals (DOAJ), African Journal Online, Bioline International, Open-J-Gate and Pharmacy Abstracts
\end{abstract}

\section{INTRODUCTION}

Gastric mucosal integrity is associated with various factors such as maintenance of microcirculation, secretion of alkaline mucus, antioxidant effects, LPO, SOD and CAT, all of which are linked to the endogenous and exogenous protection of the stomach lumen from gastro-irritants. Earlier studies have shown that disturbances in gastric mucosal blood perfusion might cause formation of ulcers and erosions [1]. The gastric mucosal antioxidant enzyme, SOD catalyzes the dismutation of superoxide radical anion $\left(\mathrm{O}_{2}^{-}\right)$into the less noxious $\mathrm{H}_{2} \mathrm{O}_{2}$ which is further inactivated by glutathione peroxidase (GPx) $[2,3]$. 
Pro-inflammatory cytokines, tumor necrosis factor- $\alpha$ (TNF- $\alpha)$, interleukin-1 $\beta$ (IL-1 $\beta)$, and interleukin-6 (IL-6) are involved in the pathogenesis of gastric ulcer [1]. Clinical and experimental data have shown that ulcerogenic factors such as stress, non-steroidal antiinflammatory drugs (NSAIDs), and $H$. pylori increase the expressions of pro-inflammatory cytokines in the gastric mucosa [4]. Hence, the antioxidant and inflammatory responses at the ulcer site might be critical for ulcer healing.

Medicinal plants from various climes have been associated with gastric ulcer treatment [5]. One of such herbs is Alpinia conchigera Griff. (Zingiberaceae), which in Malay, is called lengkuas ranting. Different parts of $A$. conchigera (e.g. rhizome, leaves and young shoots) are used as medicines for treating muscle pains, sprains, and bleeding problems. It has been reported that 1,7-disphenyl-3,5-heptanedione, a compound isolated from the rhizome of $A$. conchigeria, possesses anti-inflammatory properties [6]. Bioactive compounds like uegenol acetate, chavicol acetate and henylpropanoid have been isolated from the fruits of $A$. conchigeria [7]. Other species of Alpinia also possess various pharmacological properties [8]. The current study was aimed at investigation of the antioxidant and anti-inflammatory effects of ethanol extract of $A$. conchigera rhizomes in a rat model of gastric ulcer.

\section{EXPERIMENTAL}

\section{Chemicals and drugs}

Paraffin, $\mathrm{HCl} /$ ethanol, cyanide/ferricyanide, Tris, butylated hydroxytoluene, Tween 80, hematoxylin/eosin, $\mathrm{MNaCl}$ EDTA, glycerine, PMSF, leupeptin, xylene, $\mathrm{NaOH}$, phenolphthalein, trichloroacetic acid, thiobarbituric acid, tetrahydrobenzofluorene, and aprotinin were purchased from Sigma Aldrich Pvt. Ltd. (USA). Assay kits (ELISA) for TNF- $\alpha, I L-1 \beta$, and IL- 6 were procured from $R$ \& $D$ systems (MN, USA). All chemicals used in the current research were of analytical grade.

\section{Plant material}

Rhizomes of $A$. conchigera were collected from the Herb Garden, Jinan on November, 2017. They were taxonomically identified by a botanist (Mr. Li) affiliated to the Department of Chinese Medicine, Jinan Central Hospital, China. A voucher specimen (no. JH657821) was deposited at the herbarium of Department of Chinese Medicine, Jinan Central Hospital, China.

\section{Extract preparation}

Approximately $50 \mathrm{~g}$ of $A$. conchigera rhizome was cleaned, washed, rinsed with distilled water, and dried at $45{ }^{\circ} \mathrm{C}$ overnight. The dried $A$. conchigera rhizome was ground into powder and homogenized in $95 \%$ ethanol in the ratio of $1: 10$ (w/v) [9]. The homogenate was subjected to filtration, and the filtrate was kept in an incubator $\left(50{ }^{\circ} \mathrm{C}\right)$ for up to 4 days. The solvent was removed through rotary evaporation at $50{ }^{\circ} \mathrm{C}$, and the dry extract (approx. $1.34 \mathrm{~g}$; yield $=2.67$ $\%$ ) was kept at a temperature of $4^{\circ} \mathrm{C}$ prior to use in subsequent experiments.

\section{Animals}

Sprague-Dawley rats $(200$ - 300 g) were obtained from the Animal Unit of the Jinan Central Hospital, Jian, China. The animals were fed with a standard diet and water in an environment with $12 \mathrm{~h}$ light/12 $\mathrm{h}$ dark cycle at 22 $\pm 2{ }^{\circ} \mathrm{C}$. The animal studies were approved by the ethical committee of the Jilin University Cancer Center, China (approval no. 309/2018) and followed international guidelines [10].

\section{Induction of gastric ulcer by hydrochloric acid $(\mathrm{HCl}) / e t h a n o l$}

Gastric hemorrhage lesions were induced in the rats using $\mathrm{HCl} /$ ethanol $(0.1 \mathrm{~mL} / 20 \mathrm{~g})$ mixture $(0.15$ $\mathrm{M} \mathrm{HCl}$ in $98 \%$ ethanol) through oral administration [11].

\section{Experimental design}

The rats were kept in individual cages and subjected to $24 \mathrm{~h}$ fasting with free access to clean drinking water. The water was withdrawn 1 $\mathrm{h}$ before inducing gastric ulcer. Forty rats were randomly divided into four groups (10 rats per group). Group I (control) rats received vehicle $(0.1 \%$ Tween 80 in normal saline) orally, while group II (HCL/ethanol) rats received $\mathrm{HCl}$ /ethanol mixture orally. Group III rats received $A$. conchigera extract at a dose of $75 \mathrm{mg} / \mathrm{kg}$ body weight (bwt), while rats in group IV were given $A$. conchigera extract at a dose of $150 \mathrm{mg} / \mathrm{kg}$ bwt.

The ethanol extract of $A$. conchigera rhizome was dissolved in $0.1 \%$ Tween 80 (in normal saline) prior to administration. The dose regimens were selected based on a previous study on other Alpinia species [12].

\section{Tissue collection and preparation}

After $1 \mathrm{~h}$ of ethanol administration, the animals were euthanized under deep ether anesthesia. 
After laparotomy, the stomachs were opened and washed with normal saline to remove blood clots and gastric contents. The stomachs were blotted dry and inspected for gastric injury (expressed as ulcer index) and later investigated for gastric lesions. Then, all the stomachs were divided into portions. For histopathological analysis, one portion was fixed in $10 \%$ buffered formol saline. The portion for glandular gastric tissues was divided into 3 parts and kept at $-80^{\circ} \mathrm{C}$ for biochemical investigations. One part of the samples was homogenized in lysis buffer, $\mathrm{pH} 7.4$ consisting of $200 \mathrm{mM} \mathrm{NaCl}, 5 \mathrm{mM}$ EDTA, $10 \mathrm{mM}$ Tris, $10 \%$ glycerine, $1 \mathrm{mM}$ PMSF, $1 \mathrm{mg} / \mathrm{mL}$ leupeptin, and $28 \mathrm{mg} / \mathrm{mL}$ aprotinin, for the assay of TNF- $\alpha$, IL-1 $\beta$, and IL- 6 . Another part of the sample was homogenized in ice-cold $100 \mathrm{mM}$ phosphate buffer, $\mathrm{pH} 7.4$ for estimation of antioxidant markers (LPO, SOD, and CAT).

\section{Gastric ulcerative lesions}

The range of gastric damage was estimated by calculating the gastric lesion areas. The stomach was dissected, and blood clots were removed by rinsing with cold saline. Then, the flattened stomach of all the rats was photographed.

\section{Evaluation of ulcer index}

The stomach was opened along the better curvature and rinsed slowly under tap water. The sample was then placed on a glass slide and observed under a microscope at x10 magnification. The ulcer index were expressed as mean score value for each rat.

\section{Histological examination}

For histopathological examination, gastric tissue was fixed in $10 \%$ buffered formol saline for $24 \mathrm{~h}$. It was then washed and dehydrated with alcohol, and embedded in paraffin in an oven for an additional $24 \mathrm{~h}$. The paraffin-embedded blocks were cut into $5-\mu m$ thick sections using a microtome. The sections were examined under the light microscope after hematoxylin and eosin ( $H$ \& E) staining.

\section{Determination of $\mathrm{pH}$ and total acidity}

The $\mathrm{pH}$ of gastric juice was recorded using a digital $\mathrm{pH}$ meter. Gastric content was centrifuged and diluted with distilled water (1:10 v: v). The clear supernatant was titrated against $0.01 \mathrm{~N}$ $\mathrm{NaOH}$, using Toper's reagent until orange color formation, which corresponded to free acidity, and then titrated to pink color with phenolphthalein. The total $\mathrm{NaOH}$ titer corresponded to the total acidity. The acidity was expressed as titre of $\mathrm{NaOH} \times$ normality $\times 100 / 0.1$ milli-equivalents per litre/100g.

\section{Assessment of hemoglobin}

Buffered cyanide/ferricyanide reagent $(5 \mathrm{~mL})$ was pipetted into a clean and dry test tube. Then, $0.02 \mathrm{~mL}$ of blood was added to the tube. The solution was mixed well and incubated at $30{ }^{\circ} \mathrm{C}$. Absorbance of sample was read against distilled water after $3 \mathrm{~min}$ at $546 \mathrm{~nm}$. The concentration 'C' of hemoglobin was calculated as in Eq 1.

$C(g / 100 \mathrm{~mL})=36.77 \times A$

\section{Evaluation of cytokines}

The levels of cytokines (TNF $\alpha$, IL-1 $\beta$, and IL-6) were assayed using ELISA kits in line with the manufacturer's protocol ( $R$ \& D systems, USA). The cytokine experiment employs measurable sandwich enzyme immunoassay technique with pre-coated specific antibodies in the microplate. The rat cytokines were immersed to bind with immobilized antibody in standards, control, and samples. The unbound substances were washed and the specific rat cytokine enzyme-linked secondary antibody was added to the wells. Following development of color, the reactions were stopped, and the absorbance was read at $450 \mathrm{~nm}$. The color intensity is proportional to corresponding amount of the targets bound in the primary step. The results were expressed in $\mathrm{pg} / \mathrm{g}$ of tissue.

\section{Determination of lipid peroxidation}

The reaction was carried out in $15 \%(\mathrm{w} / \mathrm{v})$ trichloroacetic acid, $0.375 \%(\mathrm{w} / \mathrm{v})$ thiobarbituric acid and $0.25 \mathrm{~N} \mathrm{HCl}$ at $90{ }^{\circ} \mathrm{C}$ for $30 \mathrm{~min}$. The mixture was cooled and centrifuged, and the precipitate was removed. The absorbance of resulting supernatant was read at $535 \mathrm{~nm}$. The results were expressed in $\mathrm{nmol} / \mathrm{g}$ of tissue.

\section{Evaluation of SOD activity}

The SOD activity was assayed colorimetrically based on the SOD-mediated increase in the rate of autooxidation of tetrahydrobenzofluorene in alkaline aqueous solution to yield a chromophore which absorbs maximally at $525 \mathrm{~nm}$. The results were expressed in $\mathrm{U} / \mathrm{g}$ of tissue.

\section{Assessment of catalase}

Gastric mucosal scrapings were homogenized in phosphate buffer at $1-4^{\circ} \mathrm{C}$, and centrifuged. The sediment was stirred in cold phosphate buffer, and was allowed to stand in the cold with occasional 
shaking. The extraction procedure was repeated twice and the combined supernatant was used for CAT assay. The supernatant was diluted ten times with distilled water and $0.04 \mathrm{ml}$ of the diluted supernatant was used for the assay. The decomposition of $\mathrm{H}_{2} \mathrm{O}_{2}$ in presence of CAT was followed at $240 \mathrm{~nm}$. The results were expressed in $\mathrm{U} / \mathrm{mg}$ of wet tissue.

\section{Statistical analysis}

Data are presented as mean \pm standard error of the mean (SEM). SPSS 7.5 Windows (Student's version) software was used for data analysis. Statistical significance of differences between the control and treated groups were assessed using one-way ANOVA, followed by Student'sNewman-Keuls (SNK) test. Values of $p<0.05$ were considered statistically significant.

\section{RESULTS}

\section{Macroscopic features of ulcer injury}

Figure 1 shows the severity of the gastric injury as seen through macroscopic examination. Huge areas of ulcerative gastric hemorrhagic lesions were observed in gastric ulcer rats, when compared to the control animals.
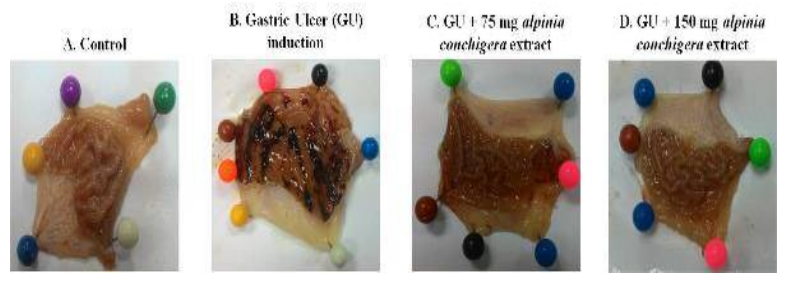

Figure 1: Macroscopic assessment of the healing of acute gastric mucosal injury induced by HCL/Ethanol in rats and its prevention by Alpinia conchigera. Section of rat stomachs obtained from $A$ : normal control rats; B: ulcerated induced rats, C: ulcer induced animals treated with $75 \mathrm{mg} / \mathrm{kg}$ Alpinia conchigera; D: ulcer induced animals treated with 150 $\mathrm{mg} / \mathrm{kg}$ Alpinia conchigera

Interestingly, rats treated with $A$. conchigera showed significant mitigation of gastric mucosal damage (inhibition of $\mathrm{Ul}$ scores), as well as reductions in the area of gastric lesions associated with $\mathrm{HCL} /$ ethanol-induced gastric ulcer. These data show that $A$. conchigera decreased the incidence of ethanol-induced gastric ulcerative lesions.

Table 1 shows the levels of gastric index markers in the control and experimental rats.

\section{Histopathological features of Alpinia conchigera-treated rat gastric mucosa}

Figure 2 shows the effect of $A$. conchigera on the histopathology of gastric damage induced by $\mathrm{HCL} /$ ethanol, relative to control rats. $\mathrm{HCL} /$ ethanol administration triggered severe gastric injury and disruption of the gastric mucosa, in addition to reduction in epithelial cells. However, $A$. conchigera-treated groups exhibited intact gastric architecture.

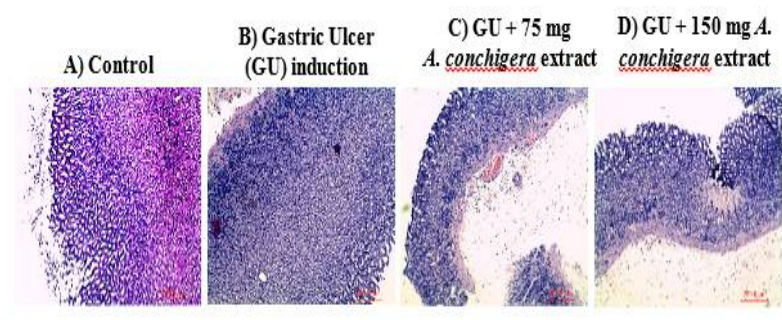

Figure 2: The histological effect of Alpinia conchigera on gastric mucosal - $\mathrm{H} \& \mathrm{E}$ staining in $\mathrm{HCl} /$ Ethanol induced gastric ulcer in rats. Section of rat stomachs obtained from $A$ : normal control rats; $B$ : ulcerated induced rats, C: ulcer induced animals treated with 75 $\mathrm{mg} / \mathrm{kg}$ Alpinia conchigera; D: ulcer induced animals treated with $150 \mathrm{mg} / \mathrm{kg}$ Alpinia conchigera

\section{Effect of Alpinia conchigera on antioxidant enzymes in rats}

The HCL/ethanol-treated rats showed significant alterations in oxidative stress markers, with increased lipid peroxidation, when compared with control rats (Figure 3). However, rats treated with A. conchigera at doses of 75 and $150 \mathrm{mg} / \mathrm{kg} \mathrm{bwt}$ had significantly attenuated oxidative stress.

Table 1: A. conchigera treated animals showed significantly lower levels of gastric index markers near towards normal rats

\begin{tabular}{|c|c|c|c|c|c|}
\hline Group & Treatment & Ulcer index & Total acidity & $\mathrm{pH}$ & Hemoglobin \\
\hline 1 & Control & $0.0 \pm 0.0$ & $113.01 \pm 6.96$ & $5.86 \pm 0.35$ & $15.5 \pm 0.61$ \\
\hline 2 & GU & $15.36 \pm 3.31^{a^{a}}$ & $144.08 \pm 12.76^{\mathrm{a}^{\circ}}$ & $3.43 \pm 0.54^{a^{-}}$ & $11.76 \pm 0.96^{a^{a}}$ \\
\hline 3 & $\begin{array}{l}\text { GU+ } 150 \mathrm{mg} \mathrm{A.c} \\
\text { extract }\end{array}$ & $10.45 \pm 1.7^{\mathrm{b}^{*}}$ & $124.18 \pm 6.51^{\mathrm{b}^{*}}$ & $4.21 \pm 0.38^{\mathrm{b}^{*}}$ & $13.68 \pm 0.61^{b^{*}}$ \\
\hline 4 & $\begin{array}{l}\text { GU+ } 150 \mathrm{mg} \mathrm{A.c} \\
\text { extract }\end{array}$ & $3.71 \pm 1.97^{\mathrm{c}^{*}}$ & $112.41 \pm 5.99^{c^{*}}$ & $4.83 \pm 0.35^{\mathrm{c}^{*}}$ & $15.31 \pm 0.63^{3^{*}}$ \\
\hline
\end{tabular}


Statistical analysis revealed significant decreases in activities of SOD and CAT in the gastric tissue after $\mathrm{HCl} /$ ethanol treatment, when compared with control group. In contrast, administration of $A$. conchigera significantly reversed the decreases in activities of CAT and SOD in a dose-dependent manner, relative to rats in respective control groups.

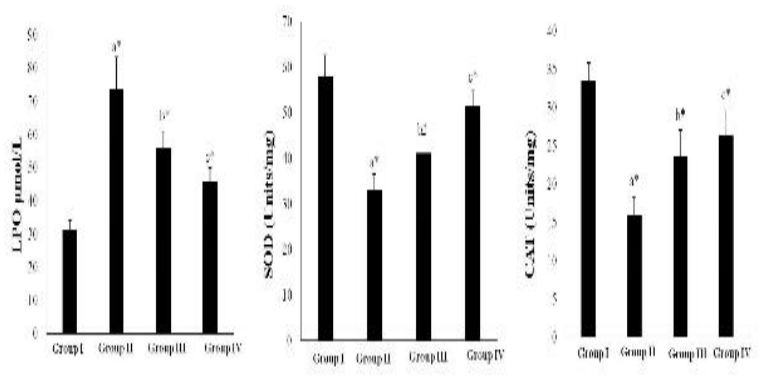

Figure 3: Effects of Alpinia conchigera on lipid peroxidation and antioxidant enzyme levels. Data are mean \pm SEM; $a^{*} p<0.05$, compared with the control; $b^{*}$ and $c^{*}$ indicate significant difference at $p<0.05$ compared with the ulcer control

\section{Effect of Alpinia conchigera extract on rat cytokine levels}

Treatment with $\mathrm{HCL} /$ ethanol produced significant increases in levels of gastric inflammatory cytokines TNF- $\alpha, \mathrm{IL}-1 \beta$, and IL-6 (Figure 4). However, $A$. conchigera-treated rats showed decreased gastric levels of these cytokines, when compared to $\mathrm{HCL} /$ ethanol-treated animals.

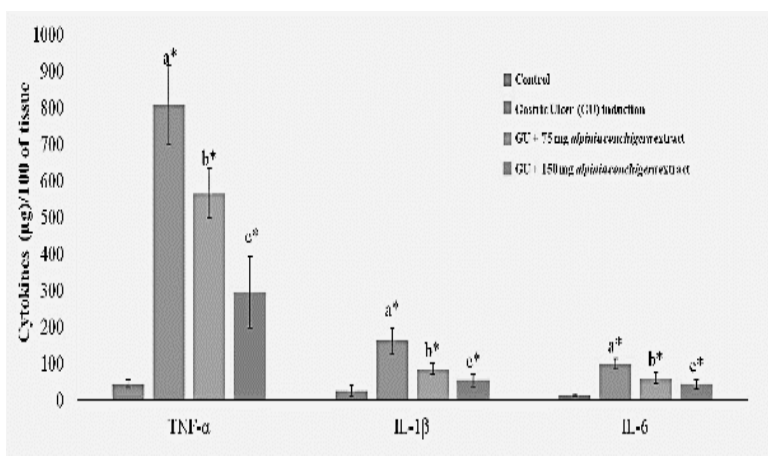

Figure 4: The effects of Alpinia conchigera on proinflammatory cytokine levels. All values are expressed as mean \pm standard error of the mean; $\mathrm{a}^{*} p$ $<0.05$ compared with the control; $b^{*}$ and $c^{*}$ indicate significant difference at $p<0.05$ compared with ulcer control

\section{DISCUSSION}

Gastric injury induced by ethanol is a popular experimental model for the assessment of preclinical studies on potential anti-ulcer effects [13]. Plant extracts are the most attractive sources of new drugs, and have produced promising outcome for the gastric ulcer treatment in numerous experimental models. Numerous phytonutrients and herbal extracts meet the increasing demand for therapeutic drugs in the pharmaceutical industry. Gastric mucosa plays an important role in the defense of gastric wall from damaging factors through formation of a barrier against these agents [14]. In this study, ulcer index scores were high in the gastric ulcer control rats, but the lesion scores were decreased in the herbal drug-treated rats. Mucosal integrity essentially offers shelter to the inner muscular and glandular layers of stomach wall. Treatment with $A$. conchigera not only protected the gastric mucosa, but also facilitated in the regeneration of the damaged regions, thereby exerting cytoprotective effects.

Free radicals are generated as by-products of exogenous factors or biological reactions. Several enzymatic and non-enzymatic antioxidants such as SOD, CAT, GPx, GSH and sulfhydryl groups scavenge reactive oxygen species (ROS); they serve as first line cellular defenses in gastric cells. Extreme generation of ROS causes increased LPO, leading to suppression of antioxidant enzyme activities [16]. The SOD enzyme converts the highly reactive superoxide anion into $\mathrm{H}_{2} \mathrm{O}_{2}$, which is in turn degraded to water by GPx and CAT.

Indomethacin, a non-steroidal analgesic and antiinflammatory drug, has been reported to reduce the levels of GSH, SOD, and CAT [17]. In gastric tissues, alcohol is linked to oxidative stress; it enhances LPO which arises through increased MDA formation and decreased GSH levels [18]. A previous study showed that manassantin A pretreatment inhibited LPO, increased mucosal GSH, and enhanced activities of SOD and CAT, prior to ethanol-induced acute gastric lesion in a rat model [19]. In the current study, $A$. conchigera significantly preserved the levels of SOD and CAT in the gastric tissues of experimental rats, indicating its cytoprotective effect.

In addition to generation of ROS, administration of ethanol induces an inflammatory response, releasing various inflammatory cytokines such as TNF- $\alpha$, IL-6, and IL-1 $\beta$ [20]. During inflammation, macrophages secrete inflammatory cytokines [21]. This decreases the gastric microcirculation adjacent to an ulcer site, causing delayed healing of the ulcer [22]. In peptic ulcer, high concentrations of IL-6 triggers release of neutrophils, monocytes/macrophages and lymphocytes at the site of inflammation, leading to increased toxic metabolites, oxidative bursts, and lysosomal enzymes all of which damage 
surrounding tissues [23]. Studies have shown that IL-1 $\beta$ plays an important role in systemic acute-phase reactions, and also in the release of additional members of the pro-inflammatory cytokines such as TNF- $\alpha$, platelet activating factor (PAF), prostaglandins (PGs), and ILs [24]. A previous study showed that manassantin A pretreatment reversed the mucosal mRNA expressions of TNF- $\alpha, \mathrm{IL}-6$, and II- $1 \beta$ in ethanolinduced gastric ulcer in rats [25].

\section{CONCLUSION}

The present study has established the gastroprotective and ulcer-healing effects of $A$. conchigera extract in a rat model of $\mathrm{HCL} /$ ethanolinduced gastric ulcer. The gastroprotective and ulcer-healing properties occur via a mechanism involving mitigation of oxidative stress and inflammation.

\section{DECLARATIONS}

\section{Conflict of interest}

No conflict of interest is associated with this work.

\section{Contribution of authors}

We declare that this work was done by the authors named in this article and all liabilities pertaining to claims relating to the content of this article will be borne by the authors.

\section{Open Access}

This is an Open Access article that uses a funding model which does not charge readers or their institutions for access and distributed under the terms of the Creative Commons Attribution License (http://creativecommons.org/licenses/by/ 4.0) and the Budapest Open Access Initiative (http://www.budapestopenaccessinitiative.org/rea d), which permit unrestricted use, distribution, and reproduction in any medium, provided the original work is properly credited.

\section{REFERENCES}

1. Kwiecieñ S, Brzozowski T, Konturek PC, Pawlik MW, Pawlik WW, Kwiecieñ N, Konturek SJ. Gastroprotection by pentoxyfilline against stress-induced gastric damage. Role of lipid peroxidation, antioxidizing enzymes and proinflammatory cytokines. J Physiol Pharmacol 2004; 55(2): 337-355.

2. Kwiecieñ S, Brzozowski T, Konturek SJ. Effects of reactive oxygen species action on gastric mucosa in various models of mucosal injury. J Physiol Pharmacol 2002; 53: 39-50.

3. Kwiecieñ S, Brzozowski T, Sliwowski Z. Helicobacter pylori infection in experimental model of ischemiareperfusion induced gastric mucosa damage. Gastroenterol Po 2001; 8: 111-125.

4. Watanabe $T$, Higuchi $K$, Tanigawa $T$, Fujiwara $Y$, Arakawa T. Mechanisms of peptic ulcer recurrence: role of inflammation. Inflammopharmacol 2002; 10:291-302.

5. Zakaria ZA, Balan T, Suppaiah V, Ahmad S, Jamaludin F. Mechanism(s) of action involved in the gastroprotective activity of Muntingia calabura. J Ethnopharmacol 2014; 151(3): 1184-1193.

6. Athamaprasangsa $S$, Buntrarongroj $U$, Dampawan $P$, Ongkavoranan $P$, Rukachaisirikul $V$, Sethijinda $S$, Sornnarintra $M$, Sriwub $P$, Taylor WC. A 1,7diarylheptanoid from Alpinia conchigera. Phytochem 1994; 37: 11-14.

7. $Y u$ J, Fang $H$, Chen $Y$, Yao Z. Identification of the chemical components of two Alpinia species. Zhongyao Tongbao 1988; 13: 132-135.

8. Araújo Pinho FVS, Coelho-de-Souza AN, Morais SM, Ferreira Santos C, Leal-Cardoso JH. Antinociceptive effects of the essential oil of Alpinia zerumbet on mice. Phytomed 2005; 12: 51-56.

9. Esra $K$, Nurgun $H$, Erdem JR, Bilge HB. Antiinflammatory and antinociceptive activity of taxoids and lignans from the heartwood of Taxus baccata $L$. J Ethnopharmacol 2003; 89: 83-89

10. National Research Council. Guide for the care and use of laboratory animals. 2011; National Academies Press.

11. Oyagi A, Ogawa K, Kakino M, Hara H. Protective effects of a gastrointestinal agent containing Korean red ginseng on gastric ulcer models in mice. BMC Complement Altern Med 2010; 10: 45.

12. Arambewela $L S$, Arawwawala $L D$, Ratnasooriya $W D$. Antinociceptive activities of aqueous and ethanolic extracts of Alpinia calcarata rhizomes in rats. $J$ Ethnopharmacol 2004; 95(2-3): 311-316.

13. Liu Y, Tian X, Gou L, Fu X, Li S, Lan N, Yin X. Protective effect of I-citrulline against ethanol-induced gastric ulcer in rats. Environ Toxicol Pharmacol 2012; 34(2): 280 287.

14. Hills BA. Gastric mucosal barrier: evidence for Helicobacter pylori ingesting gastric surfactant and deriving protection from it. Gut 1933; 34(5): 588-593.

15. Dengiz GO, Odabasoglu F, Halici Z, Cadirci E, Suleyman H. Gastroprotective and antioxidant effects of montelukast on indomethacin-induced gastric ulcer in rats. J Pharmacol Sci 2007; 105(1): 94-102.

16. Zakaria ZA, Balan $T$, Suppaiah V, Ahmad S, Jamaludin F. Mechanism(s) of action involved in the gastroprotective activity of Muntingia calabura. J Ethnopharmacol 2014; 151(3): 1184-1193.

17. Nasri H, Baradaran A, Shirzad H, Rafieian-Kopaei $M$. New concepts in nutraceuticals as alternative for pharmaceuticals. Int J Prev Med 2014; 5(12): 14871499.

Trop J Pharm Res, September 2019; 18(9): 1878 
18. Athamaprasangsa $S$, Buntrarongroj $U$, Dampawan $P$, Ongkavoranan $P$, Rukachaisirikul $V$, Sethijinda $S$, Sornnarintra $M$, Sriwub $P$, Taylor WC. A 1,7diarylheptanoid from Alpinia conchigera. Phytochem 1994; 37: 153-157.

19. Song JW, Seo CS, Kim TI, Moon OS, Won YS, Son HY, Son JK, Kwon HJ. Protective Effects of Manassantin A against Ethanol-Induced Gastric Injury in Rats. Biol Pharm Bull 2016; 39(2): 221-229.

20. Salga MS, Ali HM, Abdulla MA, Abdelwahab SI. Gastroprotective activity and mechanism of novel dichlorido-zinc(II)-4-(2-)(5-

methoxybenzylideneamino)ethyl)piperazin-1-

iumphenolat e complex on ethanol-induced gastric ulceration. Chem Biol Interact 2012; 195(2): 144-153.

21. Rozza AL, Meira de Faria F, Souza Brito AR, Pellizzon $\mathrm{CH}$. The gastroprotective effect of menthol: involvement of anti-apoptotic, antioxidant and anti-inflammatory activities. PLoS One 2014; 9(1): e86686.
22. Abdelwahab SI. Protective mechanism of gallic acid and its novel derivative against ethanol-induced gastric ulcerogenesis: Involvement of immunomodulation markers, $\mathrm{Hsp} 70$ and $\mathrm{Bcl}-2$-associated $\mathrm{X}$ protein. Int Immunopharmacol 2013; 16(2): 296-305.

23. Mei X, Xu D, Xu S, Zheng Y, Xu S. Novel role of Zn(II)curcumin in enhancing cell proliferation and adjusting proinflammatory cytokine-mediated oxidative damage of ethanol-induced acute gastric ulcers. Chem Biol Interact 2012; 197(1): 31-39.

24. Dinarello CA. A clinical perspective of IL-1beta as the gatekeeper of inflammation. Eur J Immunol 2011; 41(5): 1203-1217.

25. Kim JY, Kang JS, Kim HM, Kim YK, Lee HK, Song S, Hong JT, Kim Y, Han SB. Inhibition of phenotypic and functional maturation of dendritic cells by manassantin a. J Pharmacol Sci 2009; 109(4): 583-592. 